\title{
HEAVY METALS CONTAMINATION AND HUMAN HEALTH RISK FROM SELECTED FISH IN LAGOS NIGERIA.
}

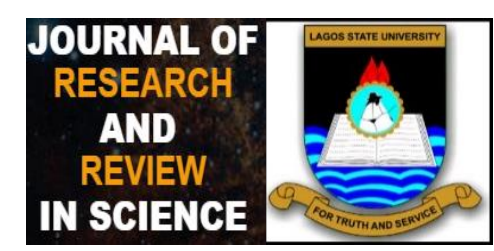

\section{Chima Nnodum ${ }^{1}$, Kafeelah Yusuf ${ }^{1}$, Comfort Adeniji ${ }^{2}$.}

${ }^{1}$ Department of Chemistry,

Faculty of Science,

Lagos State University, Nigeria.

${ }^{2}$ School of Agricultural Sciences, Lagos State University, Epe Campus, Nigeria.

\section{Correspondence}

Nnodum Chima Fausta.

Department of Chemistry,

Faculty of Science,

Lagos State University, Nigeria.

email: chimannodum2025@yahoo.com

\section{Funding information}

Authors funding

\begin{abstract}
:
Introduction: Heavy metals are known to cause deleterious effects on human health through food chain.

Aim: The study is aimed at assessing heavy metal concentrations in the tissues of four highly consumed fish species, and to evaluate the potential health risks associated with their consumption.

Materials and Methods: The concentrations of $\mathrm{Cu}, \mathrm{Cd}$ and $\mathrm{Pb}$ were analysed in the tissues of Titus (Scomber japonicus), Croaker (Pseudolithus elongatus), Scumbia (Ilisha africana) and Shrimps (Pipeus notialis) by atomic absorption spectrophotometry (AAS).

Results: The results showed that $\mathrm{Cd}$ was not detected in the tissues of all fish species sampled. There were variations among $\mathrm{Cu}$ and $\mathrm{Pb}$ concentrations in the tissues of the fish species. $\mathrm{Cu}$ had the highest concentrations $(1.00 \mu \mathrm{g} / \mathrm{g})$ in the tissues of croaker and shrimps respectively, while $\mathrm{Pb}$ had the lowest concentrations $(0.25 \mu \mathrm{g} / \mathrm{g})$ in the tissues of Scumbia. The levels of all metals in the present study were lower than the limits permitted by Food and Agriculture Organization of the United Nations/World Health Organization (FAO/WHO), European Community Regulation (EU) and European Commission (EC). Assessment of noncarcinogenic health hazard using Target hazard quotient (THQ) and hazard index ( $\mathrm{HI})$ suggested no concern from consumption of these fish species. The estimated daily intake (EDI) of the studied metals through fish consumption was below the permissible tolerable daily intake.

Conclusion: It can be concluded that there is no likely potential human health risk from consumption of the selected fish species.
\end{abstract}

Keywords: heavy metals, hazard index, target hazard quotient.

All co-authors agreed to have their names listed as authors.

This is an open access article under the terms of the Creative Commons Attribution License, which permits use, distribution and reproduction in any medium, provided the original work is properly cited.

(C) 2018 The Authors. Journal of Research and Reviews in Science - JRRS, A Publication of Lagos State University

\section{$J R R S$}

https:sciencejournal.lasucomputerscience.co 


\section{INTRODUCTION:}

Fishes are integral components of a well-balanced diet worldwide. They provide energy, proteins, vitamins and different nutrients, which are associated with health benefits and normal growth [1]. According to FAO statistics, fish accounted for about $16 \%$ of the global population's intake of animal protein and $6 \%$ of all protein consumed [2].

Pollution of the aquatic environment by heavy metals has been considered a major threat to water quality and the aquatic organisms including fishes. Their direct toxicity to man and aquatic organisms and the indirect toxicity through their accumulations in the aquatic food chain are issues of serious concern [3]. Since the diet is the main route of human exposure to heavy metals [4], the major interest was in the edible commercial species of fish. Most people in the city of Lagos obtain their fish from markets.

In Nigeria, a sizeable number of people depend on the relatively cheap, frozen fish, which are imported from different countries around the world. Thus, the knowledge about the potential accumulation of heavy metals in this fish is very important for the health of the consumers. The second source of commercial fish is the wild caught fish, which are usually captured along the coasts. Poorly treated municipal wastewater from various wastewater treatment plants, flooding, pesticides, litter and toxic waste are the main sources of pollution of the coastal zone [5]. Farmed fish represent the third source of fish. Fish farms were established in order to achieve self-sufficiency in fish production, supplementing captured fishery production and substituting the deficiency of quantities of fish sold in local markets. Cultured fishes may absorb dissolved elements and trace metals from their feeding diets and surrounding water leading to their accumulation in various tissues in significant amounts [5] and eliciting toxicological effects at target organisms [6].

Several analytical techniques such as atomic absorption spectrometry (AAS), inductively coupled plasma-atomic emission spectrometry (ICP-AES), inductively coupled plasma-mass spectrometry (ICP-MS), neutron activation analysis (NAA), differential pulse anodic stripping voltammetry (DPASV), energy dispersive X-ray fluorescence (EDXRF) and so many other techniques have been employed for the determination of trace metals in different environmental samples. AAS was used for quantifying the heavy metal contents in fish samples in the present case as it is highly selective, accurate, sensitive and cost effective [7]. Although there have been several studies reporting enrichment of heavy metals in water, sediment and fish [8, 9], studies reporting the risk assessment with special focus on human health are scarce. The risk assessment of these metals via daily dietary intake is a very important issue [10]. However, the accumulation and magnification of metals vary in different fish species. In the context, it is important to assess the concentration and potential human health risk associated with consumption of commonly consumed fish species. This study aims to determine the heavy metals in fish tissues and to compare them against the recommended maximum levels allowed in food. In addition, this study also evaluates the carcinogenic and non-carcinogenic health risk for humans through fish consumption.

\section{MATERIALS AND METHODS}

\subsection{Sample collection and preservation}

Four fish species; Titus (Scomber japonicus), Croaker (Pseudolithus elongatus), Scumbia (Ilisha africana) and Shrimps (Pipeus notialis) were purchased from four different markets namely: Agboju market, Alaba Suru market, Odunero market and Kuje market, all in Lagos. They were wrapped in polyethylene bags and transported to the laboratory. The samples were washed, tissues of each sample were removed with the aid of cleaned knife. The tissues of each fish species were homogenized and stored in the refrigerator at $4^{\circ} \mathrm{C}$. Metal contents were expressed as $\mu \mathrm{g} \mathrm{g}^{-1}$ wet wt. basis of fresh fish.

\subsection{Analytical methods}

\subsection{Instruments and reagents}

Bulk Scientific 200A atomic absorption spectrophotometer was used for the determination of $\mathrm{Pb}, \mathrm{Cd}$ and $\mathrm{Cu}$. Hollow cathode lamps were used as the excitation source. Lamp intensity and band pass were used according to the manufacturer's recommendations. Acetylene and air flow rates for all elements were 2 to 4 litres per min. The instrumental and experimental parameters used for each element, are shown in Table 1. The reagents were of analytical grade, and all solutions were prepared using distilled water. All containers and glassware were cleaned by soaking in $20 \%$ nitric acid for at least 24 hours and rinsed three times with distilled water prior to use.

\subsubsection{Sample digestion}

Measured $5.00 \mathrm{~g}$ of the homogenized tissue samples were accurately weighed into the Erlenmeyer conical flask. A digestion mixture containing $6.0 \mathrm{ml}$ of high purity nitric acid (Merck), $2 \mathrm{ml}$ of hydrochloric acid (10 M) [11] was added to each flask. The digested portions were filtered and diluted to a final volume of $50 \mathrm{ml}$ using distilled water. Acid blanks (laboratory blanks) were prepared in order to ensure that the samples and chemicals used were not contaminated. They were analyzed by atomic absorption spectrophotometry and their values subtracted to ensure that the equipment read only the exact values of heavy metals. Each set of digestion has its own acid blank and was corrected by using its blank.

\subsubsection{Analytical quality control and quality assurance}

In the present study, to check the efficiency of digestion procedures and the subsequent recovery of the metal, 
homogeneous mixtures of four samples of fish tissues

were spiked with multi element solution which contains .

Table1: Instrumental and experimental parameters for the metals analysed

\begin{tabular}{llll} 
& \multicolumn{3}{c}{ Elements } \\
Wavelength $(\mathrm{nm})$ & 324.8 & $\mathbf{P b}$ & $\mathbf{C d}$ \\
\cline { 2 - 4 } Slit width $(\mathrm{nm})$ & 0.7 & 283.3 & 228.8 \\
Analytical working range $\left(\mu \mathrm{g} \mathrm{ml}^{-}\right)$ & $0.5-5.0$ & 0.7 & 0.7 \\
Range of $\mathrm{DLs}^{*}$ & $0.02-0.13$ & $1.0-12$ & $0.05-1$ \\
& & $0.09-1.39$ & $0.04-0.22$
\end{tabular}

$\mathrm{DL}=$ detection limits

standard solutions of all metals considered in the present study. The element solution was spiked in a manner to attain final concentrations of $1.0 \mu \mathrm{g} / \mathrm{g}$. The recovery percentage results ranged from $85 \%$ to $101 \%$. A mixture without any metal was used as control. All mixtures were then subjected to the digestion procedure. The resulting solutions were analyzed three times for metal concentrations according to the same procedures as the samples to establish confidence in the accuracy and reliability of data generated.

The amount of spiked metal recovered after the digestion of the spiked samples was used to calculate percentage recovery as follows:

$$
\% \text { recovery }=[(\mathrm{t}-\mathrm{c}) / \mathrm{t}] 100 .
$$

where $t=$ concentration of a metal in treatment sample, and $\mathrm{C}=$ concentration of a metal in control sample.

Procedural blanks and standard solutions were also included for analytical quality control to assure the accuracy and reproducibility of the results.

\subsection{Calculations}

\section{3.1 Estimated daily intakes (EDI)}

The estimated daily intakes (EDI) for the analyzed metals were calculated by multiplying the respective mean concentration of the metal determined in the targeted fish samples by the weight of fish consumed by an average individual in Nigeria which was obtained from the fish consumption rate set to $68.5 \mathrm{~g}$ day-1 per person from the annual per capital fish consumption of $25 \mathrm{~kg}$ for Nigeria [12] and calculated by using the formula [13], where,

$$
\mathrm{EDI}=\mathrm{DFC} \times \mathrm{MC}
$$

DFC = daily food (fish) consumption,

$\mathrm{MC}=$ mean metal concentration in fish sample.

\subsubsection{Non-carcinogenic risk}

\section{2..3.2.1 Target hazard quotient(THQ)}

The non-carcinogenic risk assessments are typically conducted to estimate the potential health risks of pollutants using the target hazard quotient (THQ). The THQ values obtained through the consumption of fish species by local inhabitants can thus be assessed for each heavy metal and calculations made using the standard assumption for an integrated USEPA risk analysis as follows [14], where,

$$
\mathrm{THQ}=\frac{\mathrm{C} \times \mathrm{EFr} \times \mathrm{ED} \times \mathrm{FIR}}{\mathrm{BW} \times \mathrm{TA} \times \mathrm{RfD} \times 10^{-3}}
$$

where,

$\mathrm{C}$ is the heavy metal concentration in fish $(\mathrm{mg} / \mathrm{kg}$ wet weight),

FIR is the fish consumption rate set to $68.5 \mathrm{~g}$ day-1 per person from the annual per capital fish consumption of 25 $\mathrm{kg}$ for Nigeria [10],

$\mathrm{EFr}$ is the exposure frequency ( 365 days/year),

$E D$ is the exposure duration (30years or 10950 days) for non-cancer risk as used by USEPA,

$\mathrm{RfD}$ is the reference dose of individual metal as shown in Table II [15], BW is an average adult body weight $(70 \mathrm{~kg})$

TA is the average exposure time for non-carcinogens $(10,950$ days) $[16]$

If the THQ value is less than 1 , the exposed population is unlikely to experience any adverse health hazard. Conversely, if the THQ is equal to or higher than 1, there is a potential health risk [17], and relative interventions and protective measures should be taken.

Table II: Oral reference doses of heavy metals [15]

\begin{tabular}{llll} 
Heavy metal & Cd & Pb & Cu \\
\hline Rfd (mg kg-1day-1) & $1 \times 10-3$ & $4 \times 10-3$ & $4 \times 10-2$
\end{tabular}

\subsubsection{Hazard index (HI)}

It has been reported that exposure to two or more pollutants may result in additive and/or interactive effects [18]. Thus, in this study, cumulative health risk was evaluated by summing the THQ values of individual metal and expressed as Hazard index $(\mathrm{HI})$ as follows

$$
H I=T H Q(C u)+T H Q(P b)+T H Q(C d)
$$

\subsubsection{Carcinogenic risk}


Carcinogenic risk (CR) indicates an incremental probability of an individual of developing cancer over a lifetime due to exposure to a potential carcinogen. Cancer risk over a lifetime exposure to $\mathrm{Pb}$ were obtained using cancer slope factor (CSF), provided by USEPA [15]. The equation used for estimation of the cancer risk is as follows:

$$
\mathrm{CR}=\mathrm{CSF} \times \mathrm{EDI} \text { carcinogens }
$$

where,

$\mathrm{CSF}$ is the carcinogenic slope factor of $0.0085\left(\mathrm{mg} \mathrm{kg}^{-1} \mathrm{day}^{-1}\right)$ for $\mathrm{Pb}[19]$.

EDI is the estimated daily intake of heavy metals.

Acceptable risk levels for carcinogens range from $10^{-4}$ (risk of developing cancer over a human lifetime is 1 in 10000 ) to $10^{-6}$ (risk of developing cancer over a human lifetime is 1 in 1000000).

\section{2..4 Statistical analysis}

Mean concentrations in $\mu \mathrm{g} / \mathrm{g}$ wet weight were calculated. All statistical calculations were performed with SPSS 16.0 for Windows.

\section{RESULTS AND DISCUSSION}

\subsection{Concentrations of heavy metals in fish tissues.}

The concentrations of $\mathrm{Cu}, \mathrm{Cd}$ and $\mathrm{Pb}$ in tissues of four fish species highly consumed by the Nigeria people are presented in Table III. All metal concentrations were determined on wet weight basis. All results are expressed as $\mu \mathrm{g} / \mathrm{g}$ wet weight. Cadmium was not detected in all fish species. No single type of fish was consistently high with all metals. Heavy metal contents in fish samples were in the range of $0.05-1.00 \mu \mathrm{g} / \mathrm{g}$ and $0.05-0.30 \mu \mathrm{g} / \mathrm{g}$ for $\mathrm{Cu}$ and $\mathrm{Pb}$ respectively.

$\mathrm{Cu}$ is an essential element required by a wide variety of enzymes and other cell components and having vital functions in all living organisms, but very high intakes can cause adverse health problems [5]. On the other hand, $\mathrm{Cd}$ and $\mathrm{Pb}$ have no biological role, and hence they are harmful to living organisms even at considerably low concentrations. In this study, the overall average concentrations of metals were found to accumulate in the order of $\mathrm{Cu}>\mathrm{Pb}>\mathrm{Cd}$, with concentrations of essential elements higher than nonessential elements. Although it is not always the rule, these results are in conformity with the observations of Bahnasawy et al.[20] ( $\mathrm{Zn}>\mathrm{Cu}>\mathrm{Pb}>\mathrm{Cd})$. According to these data, the ranking order of mean concentration of the heavy metals in fish tissues were $\mathrm{Cu}>\mathrm{Pb}>\mathrm{Cd}$.

Table III: Mean ( $\pm S D)$ of metal concentrations $(\mu \mathrm{g} / \mathrm{g}$ wet $\mathrm{wt})$ of the selected fish species studied.

\begin{tabular}{lllll}
\hline $\begin{array}{l}\text { Scientific } \\
\text { name }\end{array}$ & Sample & $\mathbf{C d}$ & $\begin{array}{l}\text { Metal } \\
\mathbf{C u}\end{array}$ & $\mathbf{P b}$ \\
\hline $\begin{array}{l}\text { Titus } \\
\begin{array}{l}\text { Scomber } \\
\text { japonicus) }\end{array}\end{array}$ & tissue & nd & nd & nd \\
$\begin{array}{l}\text { Croaker } \\
\text { (Pseudolithus } \\
\text { elongatus) }\end{array}$ & tissue & nd & $1.00 \pm 0.04$ & $0.3 \pm 0.017$ \\
$\begin{array}{l}\text { Shrimps } \\
\text { (Pipeus notialis) }\end{array}$ & tissue & nd & $1.00 \pm 0.031$ & nd \\
$\begin{array}{l}\text { Scumbia } \\
\text { (Illisha }\end{array}$ & & & \\
Africana) & tissue & nd & nd & $0.25 \pm 0.009$ \\
\hline
\end{tabular}

nd=not detected.

\subsection{Heavy metal concentrations versus international dietary standards and guidelines.}

No Nigerian food safety standards are currently available regarding metals concentration in fish, consequently, the results obtained for tissue samples were compared with limit values and guidelines found in the bibliography using wet weights (Table IV). The levels of $\mathrm{Cu}$ and $\mathrm{Pb}$ determined in the tissues of the four studied fish species were lower than the maximum levels and guideline values described in the literature. (TablelV) 
Table IV: Maximum and standard levels ( $\mu \mathrm{g} / \mathrm{g}$ wet wt) of metals described in literature and range of concentrations found in the studied fish species.

\begin{tabular}{|c|c|c|c|c|}
\hline \multirow{2}{*}{$\begin{array}{l}\text { Organization } \\
\text { / Country }\end{array}$} & \multirow[b]{2}{*}{ Cd } & \multicolumn{2}{|l|}{ letals } & \multirow[t]{2}{*}{ References } \\
\hline & & $\mathrm{Cu}$ & $\mathbf{P b}$ & \\
\hline European Community & 0.05 & - & 0. & [21] \\
\hline England & 0.2 & 20 & 2 & [22] \\
\hline FAO (1983) & - & 30 & 0.5 & [23] \\
\hline Turkish guidelines & 0.1 & 20 & 1 & [24] \\
\hline FAO/WHO limits & 0.5 & 30 & 0.5 & [25] \\
\hline E U limits & 0.1 & 10 & 0.1 & {$[26]$} \\
\hline Saudi Arabia & 0.5 & - & 2 & [27] \\
\hline Nigeria & nd & $0.05-1.0$ & $0.10-0.30$ & present study \\
\hline
\end{tabular}

- data were not available in publication or variable was not studied. nd, not detected.

All tissue concentrations are in $\mu \mathrm{g} / \mathrm{g}$ wet weight.

\subsection{Estimated daily intake (EDI)}

The EDI of heavy metals through the consumption of fish species is given in Table $\mathrm{V}$. The result revealed that $\mathrm{Cu}$ contributed the highest daily intake and $\mathrm{Pb}$ contributed the lowest daily intake. The EDI revealed that the examined fish samples were below the recommended values hence no risk to people's health associated with the intake of the studied metals through the consumption of the selected fish samples.

Table V: Comparison of the estimated daily intake of heavy metals from different fish species studied with the recommended daily dietary allowances.

\begin{tabular}{lllll}
\hline Metal & $\begin{array}{l}\text { concentration } \\
\mathbf{m g} / \mathbf{k g}\end{array}$ & $\begin{array}{l}\text { EDI } \\
\mathbf{m g} / \text { day/ } \\
\text { person }\end{array}$ & $\begin{array}{l}\text { Recommended } \\
\text { dietary allowance } \\
\mathbf{m g} / \text { day/person }\end{array}$ & $\begin{array}{l}\text { Carcinog } \\
\text { (CR) }\end{array}$ \\
\hline $\mathrm{Pb}$ & 0.275 & 0.0188 & $0.21[26]$ & $1.60 \mathrm{E}-04$ \\
$\mathrm{Cu}$ & 1 & 0.0685 & na & \\
$\mathrm{Cd}$ & $\mathrm{na}$ & na & na & na
\end{tabular}

nd=not detected;

na $=$ not available. 


\subsection{Carcinogenic risk}

The Carcinogenic risk (CR) value of $\mathrm{Pb}$ due to exposure from the consumption of the targeted four fish species was $1.598 \times 10^{-4}$ as shown in Table V. Generally, the values of $\mathrm{CR}$ lower than $10^{-6}$ are considered as negligible, above $10^{-4}$ are considered to be unacceptable and lying in between 10-6 and 10-4 are considered as acceptable range [17]. In the present study, $\mathrm{CR}$ for $\mathrm{Pb}$ due to the consumption of fish was within the acceptable value indicating no risk of cancer.

\subsection{Noncarcinogenic risk}

The Target Hazard Quotients (THQ) for Pb, Cd, and $\mathrm{Cu}$ estimated through the consumption of four fish species are shown in Table VI. The assessment of health risk is done based on assumptions. According to USEPA, the acceptable value is 1 for THQ [14]. In the present study the THQ and Hazard Index $(\mathrm{HI})$ were less than 1 for all heavy metals suggesting no likely health risk from ingestion of these three metals individually and collectively through the fish consumption. $\mathrm{Pb}$ had the highest THQ in tissue (0.0267) for Croaker which is lower than the acceptable limits. Although the fish species from the current study were found safe for consumption, the possibility of health risk associated with non-carcinogenic effect is very low for continuous consumption for 30 years.

\subsection{Estimated daily intake (EDI)}

The EDI of heavy metals through the consumption of fish species is given in Table V. The result revealed that $\mathrm{Cu}$ contributed the highest daily intake and $\mathrm{Pb}$ contributed the lowest daily intake. The EDI revealed that the examined fish samples were below the recommended values hence no risk to people's health associated with the intake of the studied metals through the consumption of the selected fish samples

Table Vl: Target hazard quotient (THQ) for different heavy metals and their hazard index $\mathrm{S}$ ndex $(\mathrm{HI})$

from consumption of four fish species from selected markets in Lagos.

\begin{tabular}{llllll} 
Name of fish & Sample & THQCd & THQCu & THQPb & HI \\
\hline Titus & tissue & nd & nd & nd & nd \\
Croaker & tissue & nd & 0.089 & 0.0267 & 0.0356 \\
Shrimps & tissue & nd & 0.0089 & nd & 0.0089 \\
Scumbia & tissue & nd & nd & 0.0223 & 0.0223 \\
\hline
\end{tabular}

\section{CONCLUSION}

The heavy metal contents were found to vary among fish species, and the estimated daily intake of $\mathrm{Pb}$ and $\mathrm{Cu}$ from the targeted fish samples was below the respective recommended daily dietary allowance for these elements. From the human health point of view, the THQ and $\mathrm{HI}$ were less than 1 for all heavy metals, therefore, there is likely no non-carcinogenic health risk from ingestion of these three metals individually and collectively through the fish consumption. The carcinogenic risk of $\mathrm{Pb}$ due to the consumption of fish was within acceptable range indicating no risk of cancer. The heavy metal concentrations in most fishes were well below the limits proposed for fish by various international standards and guidelines such as EU (2001), FAO/WHO (1989), MAFF (2000), Turkish guidelines and Saudi guidelines.

\section{REFERENCES}

1. Ahmed MK, Baki MA, Kundu GK, Islam MS, Islam $M M$, Hossain MM. Human health risks from heavy metals in fish of Buriganga river. Springer plus. 2016;5(1):1697.

2. FAO. The international fish trade and world fisheries. 2010.<http://www.fao.org/fileadmin/user_upload/newsro om/docs/fact_sheet_fish_trade_en.pd>.

3. Adesuyi AA, Ngwoke MO,Akinola MO,Njoku $\mathrm{KL}$,Jolaoso AO. Physicochemical. Assessment of 
Sediments from Nwaja Creek, Niger Delta, Nigeria. Journal of Geoscience and Environment Protection. 2016;4:16-27.

4. AtiqueUllah AKM, Maksud MA, Khan SR, Lutfa LN, Quraishi SB. Dietary intake of heavy metals from eight highly consumed species of cultured fish and possible human health risk implications in Bangladesh.Toxicology Reports.2017; 4: 574-579.

5. Elnabris KJ, Muzyed SK, El-Ashgar NM. Heavy metal concentrations in some commercially imported fishes and their contributions to heavy metals exposure in Palestinian people of Gaza Strip (Palestine). Journal of the Association of Arab Universities for Basic and Applied Sciences 2013; 13: 44-51.

6. Ali H, Abdel-Satar A. Studies of some heavy metals in water, sediment, fish and fish diet in some fish farms in El-Fayoum Province, Egypt. Egypt. J. Aquat. Res. 2005; 31: 261-273.

7. Zhong WS, Ren T, Zhao LJ. Determination of $\mathrm{Pb}$ (Lead), Cd (Cadmium), Cr(Chromium), Cu (Copper), and $\mathrm{Ni}$ (Nickel) in Chinese tea with high-resolution continuum source graphite furnace atomic absorption spectrometry. J. Food DrugAnal.2016;24: 46-55.

8. Yusuf KA, Osibanjo O. Trace Metals in Water and Sediments from Ologe Lagoon, South western Nigeria. Pak. J. Sci. Ind. Res. 2006;49(2): 88-96.

9. Adeniyi AA, Yusuf KA, Okedeyi OO. Assessment of the Exposure of Two Fish species to Metals Pollution in the Ogun River Catchments, Ketu, Lagos, Nigeria. J. Environ. Monit. Assess, 2008;137: 451-458.

10. Martí-Cid R, Liobet JM, Castell V, Domingo JL. Dietary intake of arsenic, cadmium, mercury, and lead by the population of Catalonia. Spain Biol Trace Elements Res. 2008;125(2):120-132.

11. Manutsewee $\mathrm{N}$, Aeungmaitrepirom W, Varanusupakul $\mathrm{P}$, Imyim A, Determination of $\mathrm{Cd}, \mathrm{Cu}$, and $\mathrm{Zn}$ in fish and mussel by AAS after ultrasoundassisted acid leaching extraction. Food Chem. 2007;101:817-824.

12. FAO Fisheries-The State of World Fisheries and Aquaculture (SOFIA) PART 1: World review of fisheries and aquaculture; Fish consumption, 2008.

13. Ahmed MK, Shaheen N, Islam MS, Habibullah-alMamun M, Islam S, Mohiduzzaman M, Bhartacharjee L. Dietary intake of trace elements from highly consumed cultured fish (Labeorohita, Pagasius pangasius and Oreochromismos sambicus) and human health risk implications in Bangladesh. Chemosphere. 2015; 128:284-292.

14. USEPA, Risk assessment guidance for superfund, Human Health Evaluation Manual. EPA/540/1-89/002 vol I. Office of Emergency and Remedial Response, Washington, DC, 1989.
15 .USEPA. Risk based Concentration Table. United States Environmental Protection Agency, Philadelphia, PA; Washington DC.2000.

16. USEPA. USEPA Regional Screening Level (RSL) Summary Table: November, 2011.

17. Wang $X$, Sato $T$, Xing B, Tao S. Health risks of heavy metals to the general public in Tianjin, China via consumption of vegetables and fish. Sci. Total Environ. 2005;350:28-37.

18. Hallenbeck WH. Quantitative Risk Assessment for Environmental and Occupational Health. Lewis, Chelsea; 1993.

19. USEPA, Risk-Based Concentration Table, (2010) http://www.epa.gov/reg3hwmd/risk/human/index.htm.

20. Bahnasawy M, Khidr A, Dheina N. Seasonal variations of heavy metals concentrations in Mullet, Mugilcephalus and Lizaramada (Mugilidae) from Lake Manzala. Egypt. J. Appl. Sci. Res. 2009;5:845-852.

21. EC. European Community Commission Regulation No 78/2005(pp. L16/43-L16/45). Official Journal of the European Union (20.1.2005) 2005.

22. MAFF. (Ministry of Agriculture, Fisheries and Food).Monitoring and surveillance of non-radioactive contaminants in the aquatic environment and activities regulating the disposal of wastes at sea, 1997. In Aquatic Environment Monitoring Report No. 52.Center for Environment, Fisheries and Aquaculture Science Lowestoft, UK.2000.

23. FAO.(Food and Agriculture Organization), Compilation of legal limits for hazardous substances in fish and fishery products, FAO Fishery Circular No. 464, pp. 5-100.1983.

24. Dural M, Goksu M, Ozak A. Investigation of heavy metal levels in economically important fish species captured from the Tuzla lagoon. Food Chem. 2007;102:415-421.

25. FAO/WHO. Evaluation of certain food additives and the contaminants; mercury, lead and cadmium, WHO Technical Report, Series No. 505.1989.

26. EU. Commission Regulation as regards heavy metals, Directive,2001/22/EC, No: 466.2001.

27.SASO. Saudi Arabian Standards Organization. Maximum limits of contaminating metallic elements in foods. Riyadh, Saudi Arabia. 1997.

28. JECFA, Evaluations of the Joint FAO/WHO Expert Committee on Food Additives, 2009. 